\title{
Early Transplantation of Human Umbalical Cord Blood Stem Cell Can Improve Engrafment and Liver Response to Carbon Tetra Chloride induced Cirrhosis in Mice
}

\author{
Magdy El Barbary ${ }^{1}$, Howayda Abdel- All ${ }^{2}$, Mohamed Mohy Eldin ${ }^{3}$, \\ Amal Yousef $f^{1}$, Sahar Greish ${ }^{1}$ \\ Department of Physiology ${ }^{1}$, Department of Pathology ${ }^{2}$, Department of \\ Internal Medicine ${ }^{3}$, Suez Canal University
}

\begin{abstract}
Background: The potential use of UCB in the treatment of hepatic failure (a major problem worldwide) has been a research focus for several years now. Recent studies have identified UCB as a possible source of hepatic progenitor cells that can be differentiated into hepatocyte in vitro and in vivo and can ameliorate fibrosis. Objectives: the aim of this study was to investigate the hepatic response to transplantation of HUCB stem cells in CCl4 injured liver in mice, as regard liver function, histopathology and immunohistochemistry. Design: Experimental study. Setting: The stem cell unit in the Physiology Department and the animal house after cord blood collection in the Gynecology and Obstetric department, Faculty of Medicine, Suez Canal University. Materials and Methods: Hepatic fibrosis was induced by CCl4. HUCB stem cells were infused systemically through the tail vein immediately (group 1), and after one week of receiving CCl4 (group 2), Group 3 received only CCl4 (as a control group). Administration of CCl4 was continued for 10 weeks in G1, G2 and G3, while group 4 (as another control group) received only the solvent of CCl4 for 10 weeks. After that, blood from all groups was collected for assessment of liver function, then all mice were sacrified under general anesthesia and the liver was fixed and prepared for histopathological and immumohistochemical examination. Results: It was found that the level of alanine aminotransferase $(A L T)$ in mice treated with stem cells after CCl4 administration was significantly lower while serum albumin was significantly higher compared to group 3 animals who received CCl4 without stem cells treatment $(P=0.001)$. Whereas serum total and direct bilirubin levels were similar among all groups. histopathological examination revealed that hepatic damage was less in the stem cells treated mice (G1 and G2) than in non treated group (as regards liver cell changes, portal tract inflammation, piecemeal necrosis, portal tract fibrosis and bridging fibrosis). However, liver inflammation and fibrosis were more in mice treated after one week than in immediately treated mice. Immumohistochemical examination, more importantly, IHC staining with monoclonal mouse anti-human hepatocyte revealed presence of human hepatocytes in injured mice liver which proved that the transplanted stem cells were transdifferentiated into hepatocyte. Conclusion: HUCB stem cells were transdifferentiated into hepatocyte when infused in mice injured liver and cause improvement in liver function test and liver histology. Key words: carbon tetrachloride (CCl4), Human Umbilical Cord Blood stem cells, liver fibrosis and monoclonal mouse anti-human hepatocyte.
\end{abstract}




\section{INTRODUCTION}

Although liver transplantation has become a standard procedure for patients with liver failure, a number of issues in the management of these cases remain to be addressed, in particular organ shortage and poor outcome in patients not supported by liver transplant. In order to overcome these problems, alternative approaches have been proposed, such as auxiliary and split-liver transplantation, procurement from living donors, isolated cell transplantation, transgenic xenotransplantation or extracorporal liver support. In particular, cell-based therapies, comprising isolated hepatocyte transplantation ${ }^{(2)}$. Recent advances in the liver repopulation field and the considerable excitement surrounding the use of hematopoietic stem cells (HSC) for regenerative medicine allow us to explore new possibilities. Several studies performed in animal models highlighted the potential of HSC to both differentiate into hematopoietic cell lineages and apparently transdifferentiated into nonhematopoietic cells, such as hepatocytes, neurons, astrocytes, skeletal muscle and cardiac muscle cells, pulmonary epithelium, renal tubular cells and pancreatic islet cells $^{(3)}$. The potential use of UCB in the treatment of hepatic failure (a major problem worldwide) has been a research focus for several years now. Recent studies have identified UCB as a possible source of hepatic progenitor cells that can be delivered to the liver by portal or systemic circulation. These types of investigations have typically involved damaging the liver in some manner (partial hepatectomy, irradiation or chemically), and then examining for the presence of hepatic progenitor cells ${ }^{(5,14)}$. In the present study, we want to identify whether UCB, which are a rich source of stem cells, would be able to differentiate into hepatocytes when infused intravenously in CCl4 mice model.

\section{MATERIALS \& METHODS}

\section{Materials}

1-Animals

Albino female mice 6 weeks old, $40 \mathrm{gm}$ weight were used in this study. Animals were brought from the Ophthalmic Research Institute Center for experimental animals in Giza, were acclimatized for one week and kept with free access to standard pellet animal diet and tap water under controlled conditions of room temperature. Mice were equally divided into the following four groups, each containing 13 mice: Group (1): immediately treated with stem cells after receiving $\mathrm{CCl}_{4}$. Group (2): treated with stem cells 1 week after receiving the first dose of $\mathrm{CCl}_{4}$. Group (3): not treated with stem cells (received only $\mathrm{CCl}_{4}$ in a dose similar to that of G1 and G2), as a control group. Group (4): received only corn oil (solvent of $\mathrm{CCl}_{4}$ ), as another control group.

\section{2-Cord blood collection}

Sterile collection tubes containing citrate phosphate dextrose adenine-l (CPDA-l) anticoagulant were used for collection of the cord blood. Sterile syringe and disposable gloves was used. 


\section{3- Reagents}

3-1- Reagents for stem cell separation

1. Isolation buffer: which consists of $100 \mathrm{ml}$ Phosphate buffered saline (PBS) $+10 \mathrm{ml}$ (RPM1) + $1 \mathrm{ml} \mathrm{10 \%}$ fetal calf serum (FCS).

2. Lymphocyte separation medium, Ficoll hypaqe (Sigma)

3. Dynabeads M-450 CD34 are supplied as a suspension of $4 \times 108$ beads $/ \mathrm{ml}$ in phosphate buffered saline (PBS), pH 7.4, containing $0.1 \%$ human serum albumin (HSA) and $0.02 \%(\mathrm{NaN} 3)$.

4. DETACHaBEAD CD34 is affinity purified polyclonal antibodies. It is supplied sterile filtered in $\mathrm{PBS}, \mathrm{pH}$ 7.4 .

5. Magnetic separation device [Magnetic Particle Concentrator (DYNAL MPC-I)].

\section{3-2- Reagents for pathology}

\section{3-2-1- Histopathology:}

a-Hematoxylin and Eosin dye for histopathologic evaluation.

b-Masson trichrome to evaluate the extent of fibrosis.

\section{3-2-2- Immuonohistochemistry}

(IHC):

1. Positive charged slides: Biogenix optiplus slides Cat No XT002-SL.

2. Primary antibodies: Mouse monoclonal antibody for Human Hepatocyte, Dako Cat No M7158, Clone: OCH1E5, Isotype: IgG 1, Kappa (working dilution 1:25).

3- Detection kit (Labvision):

a-Hydrogen peroxide: 3\% hydrogen peroxide in water.

b-Blocking serum: goat antimouse IgG (sc 2039) working dilution 1:100.

c-Prediluted biotinylated secondary antibody: made in horse and recognizes rabbit, mouse, goat, rat, sheep, as well as bovine IgG.

d-Preformed streptavidin/peroxidase complex solution.

e-Chromogen: Diaminobenzidine tetrahydrochloride (DAB).

\section{Methods}

1- Study design: experimental study.

2- Site of study: The study was carried out in the stem cell unit in the Physiology Department, Faculty of Medicine, Suez Canal University after cord blood collection in the Gynecology and Obstetric department, Faculty of Medicine, Suez Canal University.

3- Induction of liver fibrosis: Fibrosis was carried out by giving $\mathrm{CCl}_{4}(2 \mathrm{ml} / \mathrm{kg}$ body weight dissolved in $150 \mu \mathrm{l}$ of corn oil solution) one subcutaneous injection every three days for 10 weeks, with a total dosage of $60 \mathrm{ml} / \mathrm{kg}$.

\section{4- Isolation of CD34+ stem cells \\ 4-1- Cell source}

The UCB was collected from normal volunteers according to the following:

Inclusion criteria: Full term normal vaginal delivery.

Exclusion criteria: The UCB collection is excluded from females with known history of hepatitis, infectious diseases, diabetes mellitus, severe hypertension, abortions or bad obstetric history.

The collections were made prior to the expulsion of the placenta. The UCB was collected while the placenta was still in utero. Using strict aseptic techniques, the umbilical vein was cleansed with alcohol followed by betadine. The umbilical vein was pierced and UCB collected into sterile collection tubes containing $5 \mathrm{ml}$ of citrate phosphate dextrose adenine-l 
(CPDA-l) anticoagulant with total collection of $50 \mathrm{ml}$ UCB. Samples were collected separately and stored at $4{ }^{\circ} \mathrm{C} \&$ processed within $24 \mathrm{hrs}$ (17).

\section{4-2- Separation and Purification of} CD34+ cells

Separation of UCB CD34+ stem cells was carried out according to method described by (Milteny et al., 1990) ${ }^{(7)}$ by immuno-magnetic separation technique.

Upon mixing and incubation (CD34+ cells bind to Dynabeads M450 CD34 and the rosetted cells are isolated from the suspension by using a DYNAL Magnetic Particle Concentrator (DYNAL MPC). A subsequent incubation with DETACHaBEAD CD34 gently detaches isolated cells from the beads. A DYNAL MPC is then used to separate the purified, positively selected CD34+ cells from the released Dynabeads M-450 CD34.

4-3- Assessment of the quantity \& the quality of the separated cells

- The quantity of the isolated CD34+ cells were assessed by putting the sample on automated cell counters.

- The quality of the isolated CD34+ cells were determined by using tyrpan blue dye exclusion test: the viable cells were not stained ${ }^{(13)}$.

\section{5- Transplantation of HUCB stem} cells

After preparation of UCB stem cells, a dose of $10^{6}$ UCB stem cells/mice were injected IV in the dorsal tail vein after inducing venodilataion by rubbing the tail with alcohol.

\section{6- Handling of the liver specimens}

- For each mouse, a paraffin block from the liver was prepared.
- From each paraffin block, serial $5 \mu$ thick tissue sections were obtained and processed through the following:

\section{6-1- Histopathology}

Two $5 \mu$ paraffin sections from each block were stained with hematoxylin and $\operatorname{eosin}^{(\mathbf{1 2})}$. Morphological analysis was performed to determine the liver architecture, portal tract inflammation, portal tract fibrosis, liver fibrosis and piecemeal necrosis. In addition, the extent of fibrosis was further confirmed on masson trichrome.

\section{6-2- Immunohistochemistry}

Five sections were mounted on the positive charged slides for IHC and stained with monoclonal mouse antihuman hepatocyte.

\section{Controls}

In each staining session: a slide of human liver (obtained from Pathology Lab., Suez Canal University Hospital) known to be positive for the mouse monoclonal anti-human hepatocyte was used as a positive control. A slide of non-treated mice liver known to be negative for the monoclonal mouse anti-human hepatocyte was used as a negative control.

Then the IHC stained slides were examined to determine: the presence of immunopositive human hepatocyte in the mice liver by the presence of distinct, cytoplasmic, granular brownish staining ${ }^{(1)}$.

\section{7- Image-based analysis system}

The percentage of immunopositive human hepatocyte in the liver sections of the mice treated with human CD34+ stem cells was calculated using image-based analysis system (Supereye Heidisoft). The number of immunopositive cells was 
estimated by manual counting. Then it was divided by the total number of cells giving the percentage of immunopositive cells. Fifteen captures were taken per mice (five captures per section and three sections per mice).

\section{8- Statistical analysis}

Data were analyzed with the SPSS statistical software program (SPSS Inc.) and all summary statistics for numerical data (quantitative continuous data) were presented as means \pm standard deviation (SD). Serum ALT, albumin, total and direct bilirubin were compared among the studied group with analysis of variance (ANOVA), followed by posthoc test. The level of significance was at $(\mathrm{p}<0.05)$. Frequency and percentage were done for qualitative data. Chi. Square test was used to assess the difference among the four groups for qualitative nominal data.

\section{9-Ethical consideration}

Informed consent was taken from each pregnant woman before umbilical cord blood sample was taken. Patient was informed that there was no risk about her health or her child health from taking UCB sample. Any woman has the right to withdraw from the study without giving reasons. Animals was handled gently, housed with suitable environmental and nutritional conditions, assessed for general health and body weight and anesthetized before sacrifice.

\section{RESULTS}

Chemistry: level of ALT and albumin were significantly different among the four groups, table (1).

\section{Pathology}

Immunohistochemical staining findings

\section{1-Differentiation of CD34+ cells into human hepatocytes}

Liver sections from the negative control group (G4) shows absence of immunoreactivity for the anti-human hepatocyte (Fig. 1), while strong cytoplasmic granular staining is encountered in the section of human liver (Fig. 2). Livers from albino mice transplanted with ${\mathrm{CD} 34^{+}}^{+}$cells are assessed by IHC. CD34 ${ }^{+}$cells gave rise to individual and/or clusters of human hepatocytes in mouse livers based on their morphology and the presence of granular cytoplasmic specific staining for anti-human hepatocyte. The immunoreactive cells are mostly arranged in the perivascular tissue (Fig. 3) ' This indicates that human CD34+ cells circulating into the liver of the mice "transdifferentiated" within the mouse injured liver microenvironment.

\section{2- Image analysis}

It is found that the percentage of human hepatocyte in injured mice liver was variable in the two groups injected with the human CD34+ stem cells $(\mathrm{G} 1, \mathrm{G} 2)$ as estimated by manual counting operation using image-based analysis system. The difference in the percentage of immunopositive cells is statistically significant between G1 and G2 (table 3).

\section{DISCUSSION}

Recent studies have demonstrated that stem cells have greater plasticity and can differentiate down multiple cell lineages in rodents ${ }^{(15)}$. Much of these kinds of works have used bone marrow cells. Since bone marrow aspiration from the patient is an invasive procedure, the clinical use of bone marrow cells may be dangerous 
for risky patients with severe complications. UCB is a source for HSCs, and transplantation of UCB has been part of clinical practice for more than 10 years ${ }^{(\mathbf{1 7})}$. Recently, it has been reported that UCB can differentiate into hepatocytes ${ }^{\mathbf{( 1 8 )}}$. In addition, UCB cells can be collected without any harm to the newborn infants, and HSCs from UCB can be cryopreserved until transplantation. For these reasons, UCB could be a prominent source for various kinds of cell therapy.

Therefore, this study was designed to determine the mechanism of hepatic response to UCB stem cells transplantation in $\mathrm{CCl}_{4}$ injured liver. It consisted of four groups of nonimmunosupressed mice; G1 was treated with stem cells immediately after $\mathrm{CCl}_{4}$ injection, G2 was treated with stem cells after one week from the first dose of $\mathrm{CCl}_{4}$ injection, G3 was not treated with stem cells and received $\mathrm{CCl}_{4}$ only and G4 not treated with stem cells and did not receive CCl4 (control group).

There were no previous records demonstrating that $\mathrm{CCl} 4$ affects the viability or the function of stem cells, therefore in this study we injected stem cells immediately (G1) and 1 week after receiving CCl4 (G2) and was continuously administrated for 10 weeks.

Before beginning this work, a pilot study was effectuated based on the work of Fang et al. ${ }^{(\mathbf{4})}$. The induction of hepatic fibrosis was achieved after 10 weeks contrary to the previous work $^{(4)}$ using 5 weeks. This may be due to the different mice generation, and different temperature and humidity in addition to the purity and efficacy of the drug $\left(\mathrm{CCl}_{4}\right)$.

The time of HUCB stem cells administration, whether immediately or after one week is an important determinant for their therapeutic effects. Shi et al. ${ }^{(\mathbf{1 0})}$ found that delaying stem cell administration by one week after $\mathrm{CCl}_{4}$ challenge did not affect their engraftment, but hampered their ability to prevent disease progression. This may be caused by the irreversible course of $\mathrm{CCl}_{4^{-}}$ induced injury, which, once it happened, cannot be rescued by HUCB stem cells administration.

The absence of rejection to UCB stem cells may be due to unique immunological properties of both the stem cell and non-stem cell components of cord blood, it may be possible to utilize allogeneic cells for regenerative applications without needing to fully compromise the recipient immune system ${ }^{(\mathbf{9})}$.

In the current study, the degree of liver function and fibrosis were better in G1 than in G2 but still better in G2 than in G3. ALT was significantly lower in G1 mice and in G2 mice compared to that in G3, However, ALT level in G1 is less than that in G2 when compared with G3. Fang et al. ${ }^{(4)}$ and Yagi et al. ${ }^{(19)}$ found that the level of the ALT in mice treated with stem cells transplantation after $\mathrm{CCl}_{4}$ administration were significantly lower compared to those of only $\mathrm{CCl}_{4}$ group without stem cells transplantation. Therefore, they hypothesized that transplantation of UCB stem cells can promote proliferation of the functional hepatic cells of the host. 
In this study, there were no statistical significant differences in serum total and direct bilirubin among mice in G1, G2 and G3. A similar observation was ruled by Fang et al. ${ }^{(4)}$ who found that serum total and direct bilirubin levels were similar among mice treated and those not treated with stem cells along with $\mathrm{CCl}_{4}$. The explanation is unknown but possibly this may be due to failure of the new hepatocytes developed from the transplanted stem cells to uptake and/or to conjugate and/or secrete bilirubin.

In the current study, albumin was significantly more in G1 mice and in G2 mice compared to that in G3. However, albumin level in G1 was significantly more than that in G2. Similarily, Yagi et al. ${ }^{(\mathbf{1 9})}$ found that transplantation of the bone marrow stem cells into $\mathrm{CCl}_{4}$ liver-injured rats restored their serum albumin level. This is a good indicator that the transdifferentiated hepatocytes were functional as the hepatocytes were the only source of albumin in mice as well as humans.

In this study, data of histopathology was represented as the following items: liver architecture and liver cells changes, portal tract inflammation, piecemeal necrosis, portal tract fibrosis and bridging fibrosis and was not represented as grading or scoring because Knodell score is a numerical scoring system for assessing histological activity in asymptomatic chronic active hepatitis and not used in $\mathrm{CCl}_{4}$ induced liver fibrosis ${ }^{(6)}$.

It was found that the liver injury in treated groups were lower than that of nontreated group. However, the hepatic tissue recovery from damage was much improved in G1 mice when compared with G2. This indicates that UCB stem cells had the ability to rescue $\mathrm{CCl}_{4}$-damaged liver, which might contribute to the restoration of organ function.

Histological examination revealed that 10 weeks of receiving $\mathrm{CCl}_{4}$ without stem cells treatment (G3) showed preserved liver architecture but with varying degree of cells changes, inflammation of the portal tract, piecemeal necrosis, portal tract fibrosis and bridging fibrosis in all mice of the group. This is similar to Fang et al. ${ }^{(4)}$ who found that areas of liver degeneration and necrosis in mice received $\mathrm{CCl}_{4}$ were significant more than stem cells treated mice.

Whereas in G1 which was treated with HUCBSCs immediately after receiving $\mathrm{CCl}_{4}$, the liver architecture was preserved with $28.6 \%$ having no liver cells changes and $14.3 \%$ having no portal tract inflammation. Neither piecemeal necrosis nor portal tract fibrosis was found in any of the liver specimens in this group. Also 42.9\% had no bridging fibrosis. Sakaida et al. ${ }^{(8)}$ found that the hepatic damage improvement in the histological examinations was much better in the stem cells treated mice

Animals treated with stem cells one week after receiving the first $\mathrm{CCl}_{4}$ dose (G2) in spite of having preserved liver architecture yet all had liver cells changes in the form of mild liver cells ballooning in $28.6 \%$ and moderate liver cells ballooning in $71.4 \%$. In addition portal tract inflammation was moderate in $42.9 \%$, marked in $57.1 \%$. Piecemeal necrosis was mild in $42.9 \%$, moderate in $57.1 \%$. Portal tract 
fibrosis was absent from all liver specimens of this group, but bridging fibrosis was present in all of them with short fibrous septum in $42.9 \%$ and mild bridging in $57.1 \%$.

When compared with G3 mice, the portal tract inflammation, piecemeal necrosis and bridging fibrosis were statistical significantly lower in G1 and G2 than in G3. However, piecemeal necrosis and liver fibrosis were more in G2 than in G1. These data showed that hepatic tissue recovery from damage was much better in G1 mice when compared with G2 ones.

In the present study, CD34+ UCB cells converted into human hepatocytes, suggesting that CD34+ cells are rich in hepatic progenitor cells. Livers from mice in the treated groups were found to contain cells that stained positively for anti-human hepatocyte antibody, while none of the control mouse livers demonstrating such staining. Normal human liver served as the positive control for this analysis. Only hepatocytes, not bile duct cells or other non-parenchymal cells, were positively stained in the human liver section. It was found that the percentage of human hepatocyte in injured mice liver was variable in the two groups about $3.49 \%$ in $\mathrm{G} 1$ and $1.81 \%$ in $\mathrm{G} 2$.

Our results were identical to Shyu et al. ${ }^{(\mathbf{1 1})}$ who had the same finding that UCB stem cells have the capacity to differentiate into cells with human hepatocyte characteristics in mouse liver following injury and found that the ratio of human hepatocyte repopulation was $2.45 \%$, 6 weeks after UCB cell injection. Di Campi et al. ${ }^{(3)}$ found that human stem cells were able to transdifferentiated into hepatocytes, to improve liver regeneration after damage and the percentage of human hepatocyte in mice liver was $1.1 \%$, after 4 weeks of UCB stem cell injection.

Tanabe et al. ${ }^{(14)}$ revealed that the CD34+UCB cells are rich fractions in hepatic progenitor cells and found that human hepatocyte specific antigen positive cells were distributed throughout the mice liver after $\mathrm{CCl}_{4}$ injury. Of 5542 hepatocytes, 90 (1.7\%) hepatocytes expressed humanspecific antigen when stained with anti-human hepatocyte monoclonal antibody one month after transplantation of CD34+UCB cells.

The reason for such a difference in the percentage of human hepatocyte in the mice injured liver may be methodological. For instance, in our study UBC stem cells were administered via tail vein by dose of $1 \times 10^{6}$ CD34+ cells, while Shyu et al. ${ }^{\text {(11) }}$ utilized intrasplenic injection of $2 \times 10^{6}$ MNCs. However, Di Campi et al. ${ }^{(3)}$ isolate CD34+ cells which were injected intraperitoneally by dose of 4 x $10^{5}$ mouse. While Tanabe et al. ${ }^{(14)}$ transplanted $3 \times 10^{4}$ CD34+ cells, two days after injection of $\mathrm{CCl}_{4}$ via portal vein infusion. We believed that differences in the time course, route of administration, number of stem cells transplanted and other experimental conditions might explain the different outcome of our protocol when compared to the above mentioned studies.

We concluded that the infusion of CD34+ stem cells into the liver in the early stage of damage might initiate endogenous hepatic tissue 
regeneration that opposes the injury inflicted by toxicants.

Furthermore, we have affirmed previous findings suggesting that UCB cells possess the ability to differentiate into human hepatocytes in mouse liver after injury. This information might be useful in future studies regarding the utility of UBC derived cells in liver transplantation therapy.

Table (1): Comparison among all groups according to liver functions tests.

\begin{tabular}{|l|l|l|l|l|}
\hline $\begin{array}{l}\text { Liver } \\
\text { Function tests }\end{array}$ & ALT(U/ml) & $\begin{array}{l}\text { Total } \\
\text { Bilirubin(g/L) }\end{array}$ & $\begin{array}{l}\text { Direct } \\
\text { Bilirubin(g/L) }\end{array}$ & Albumin(g/L) \\
\hline G1 & $52 \pm 13.8$ & $0.41 \pm 0.09$ & $0.24 \pm 0.08$ & $2.97 \pm 0.18$ \\
\hline G2 & $87.9 \pm 6.8$ & $0.44 \pm 0.11$ & $0.21 \pm 0.07$ & $2.34 \pm 0.21$ \\
\hline G3 & $107 \pm 8.5$ & $0.48 \pm 0.09$ & $0.21 \pm 0.08$ & $2.13 \pm 0.14$ \\
\hline G4 & $37.2 \pm 0.5$ & $0.32 \pm 0.04$ & $0.15 \pm 0.05$ & $3.43 \pm 0.11$ \\
\hline F value & 113.7 & 5.4 & 2.3 & 112.7 \\
\hline P value & $0.001^{*}$ & 0.06 & 0.09 & $0.001^{*}$ \\
\hline
\end{tabular}

* Statistically significant.

Table (2): Comparison between all groups according to morphological change in liver tissue

\begin{tabular}{|c|c|c|c|c|c|c|}
\hline \multicolumn{2}{|c|}{ Morphological changes } & G1 & G2 & G3 & G4 & $\begin{array}{c}\text { P } \\
\text { value }\end{array}$ \\
\hline \multirow{3}{*}{$\begin{array}{l}\text { Liver } \\
\text { architecture } \\
\text { and liver cell } \\
\text { changes }\end{array}$} & Preserved, no changes & $28.6 \%$ & $0 \%$ & $0 \%$ & $100 \%$ & \multirow{3}{*}{0.001} \\
\hline & $\begin{array}{l}\text { Preserved, mild } \\
\text { ballooning }\end{array}$ & $28.6 \%$ & $28.6 \%$ & $11.1 \%$ & $0 \%$ & \\
\hline & $\begin{array}{l}\text { Preserved, moderate } \\
\text { ballooning }\end{array}$ & $42.8 \%$ & $71.4 \%$ & $88.9 \%$ & $0 \%$ & \\
\hline \multirow{4}{*}{$\begin{array}{l}\text { Portal tract } \\
\text { Inflammation }\end{array}$} & No inflammation & $14.3 \%$ & $0 \%$ & $0 \%$ & $100 \%$ & \multirow{4}{*}{0.001} \\
\hline & Mild inflammation & $57.1 \%$ & $0 \%$ & $22.2 \%$ & $0 \%$ & \\
\hline & Moderate inflammation & $14.3 \%$ & $42.9 \%$ & $11.1 \%$ & $0 \%$ & \\
\hline & Marked inflammation & $14.3 \%$ & $57.1 \%$ & $66.7 \%$ & $0 \%$ & \\
\hline \multirow{3}{*}{$\begin{array}{l}\text { Piecemeal } \\
\text { necrosis }\end{array}$} & No necrosis & $100 \%$ & $0 \%$ & $0 \%$ & $100 \%$ & \multirow{3}{*}{0.001} \\
\hline & Mild necrosis & $0 \%$ & $42.9 \%$ & $33.3 \%$ & $0 \%$ & \\
\hline & Moderate necrosis & $0 \%$ & $57.1 \%$ & $66.7 \%$ & $0 \%$ & \\
\hline \multirow{3}{*}{$\begin{array}{l}\text { Portal tract } \\
\text { fibrosis }\end{array}$} & No fibrosis & $100 \%$ & $100 \%$ & $0 \%$ & $100 \%$ & \multirow{3}{*}{0.001} \\
\hline & Mild fibrosis & $0 \%$ & $0 \%$ & $44.4 \%$ & $0 \%$ & \\
\hline & Moderate fibrosis & $0 \%$ & $0 \%$ & $55.6 \%$ & $0 \%$ & \\
\hline \multirow{4}{*}{ Liver fibrosis } & No fibrosis & $42.9 \%$ & $0 \%$ & $0 \%$ & $100 \%$ & \multirow{4}{*}{0.001} \\
\hline & $\begin{array}{l}\text { Short fibrous } \\
\text { septum }\end{array}$ & $57.1 \%$ & $42.9 \%$ & $0 \%$ & $0 \%$ & \\
\hline & Mild bridging & $0 \%$ & $57.1 \%$ & $44.4 \%$ & $0 \%$ & \\
\hline & $\begin{array}{l}\text { Moderate } \\
\text { bridging }\end{array}$ & $0 \%$ & $0 \%$ & $55.6 \%$ & $0 \%$ & \\
\hline
\end{tabular}


Table (3): Mean percentage of immunopositive human hepatocyte in G1, G2

\begin{tabular}{|l|l|l|}
\hline & G1 & G2 \\
\hline Mean \pm SD & $3.49 \% \pm 0.0039$ & $1.81 \% \pm 0.0049$ \\
\hline Min & $3.06 \%$ & $1.05 \%$ \\
\hline Max & $4.02 \%$ & $2.40 \%$ \\
\hline
\end{tabular}

$P$ value $=0.001$

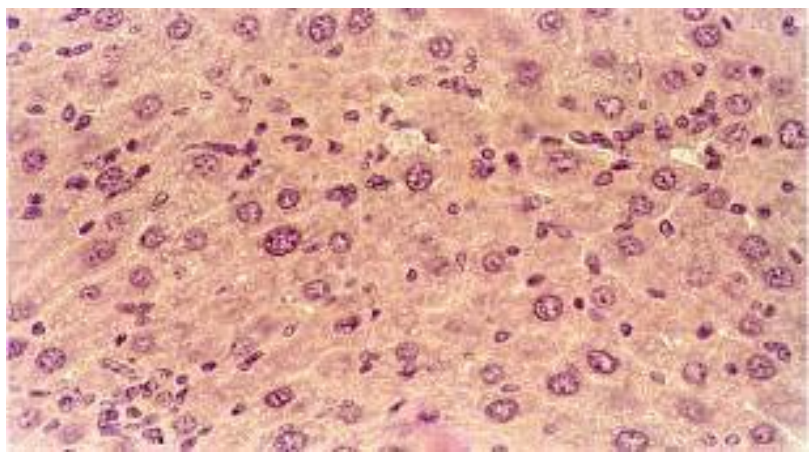

Fig. (1): Section from liver tissue of G4 (control Mice) showing absence of staining. (IHC Anti-human hepatocyte, DAB chromogen, Harris's Hematoxylin counterstain X400).

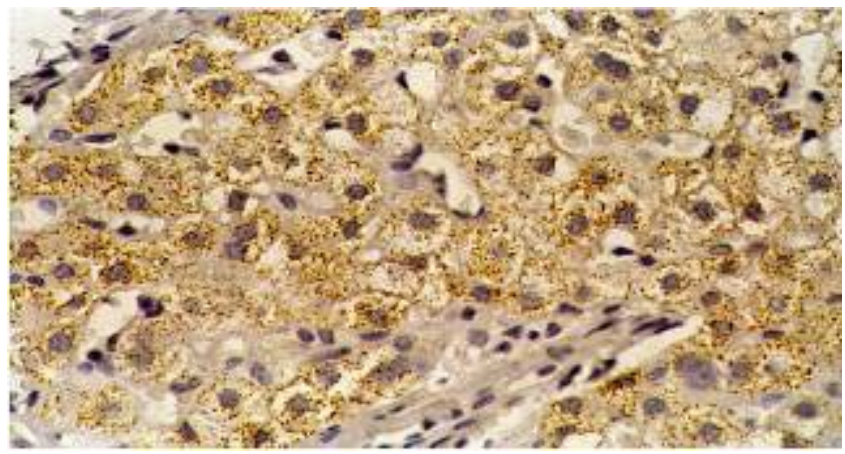

Fig. (2) Section from (human liver) showing strong cytoplasmic brownish granules. (IHC Anti-human hepatocyte, DAB chromogen, Harris's Hematoxylin counterstain X400). 

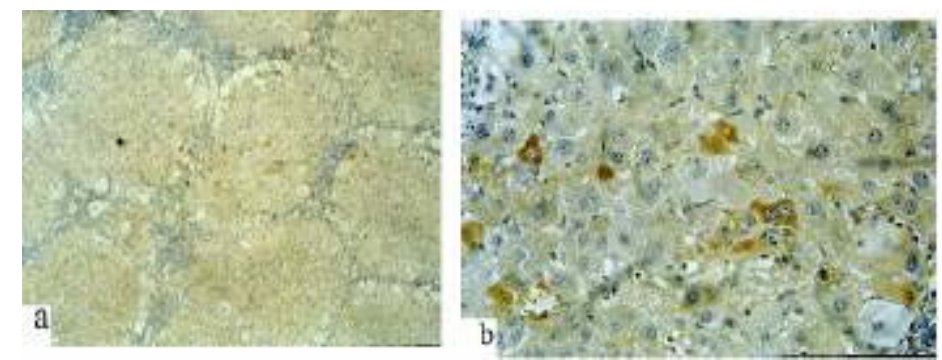

Fig. (3-1) Section from liver tissue of G1 showing the immunopositive stained cells (human cells). The staining was cytoplasmic and granular. (IHC Anti-human hepatocyte, DAB chromogen, Harris's Hematoxylin counterstain; a: X100, b: high power magnification of a X400).

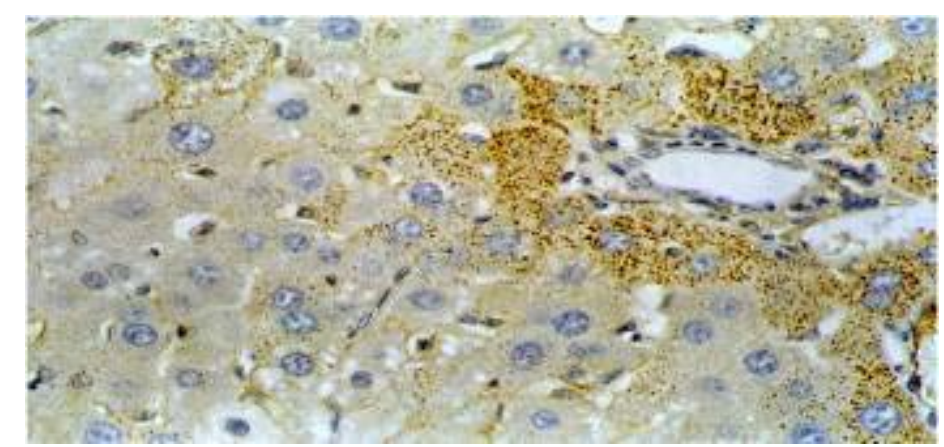

Fig. (3-2) Section from liver tissue of G2 showing the immunopositive stained cells. The staining was cytoplasmic and granular. (IHC Antihuman hepatocyte, DAB chromogen, Harris's Hematoxylin counterstain X400).

Fig (3) Group 1\&2 Mice liver tissue stained with (IHC Anti-Human Hepatocytes)
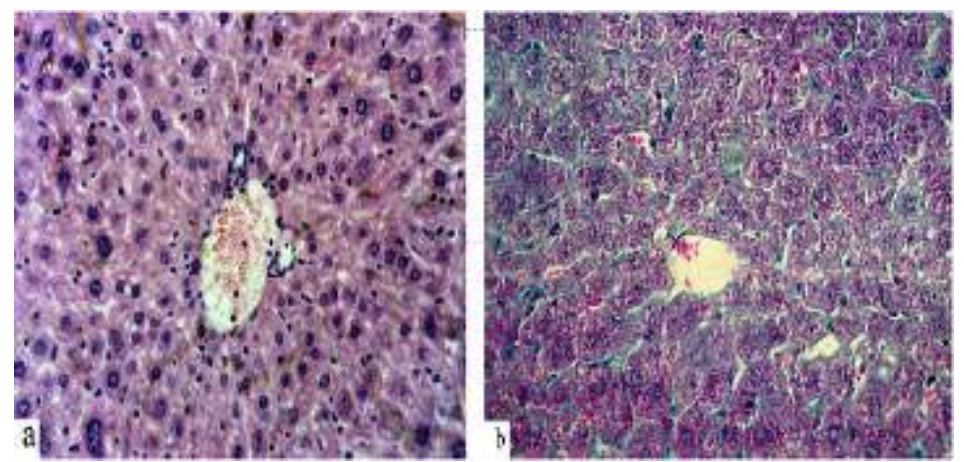

Fig. (4-1) Section from liver tissue of G4 showing normal liver tissue; preserved architecture, No portal tract fibrosis, No piecemeal necrosis (a: $H \& E X 400, b$ : Masson Trichrome X400). 

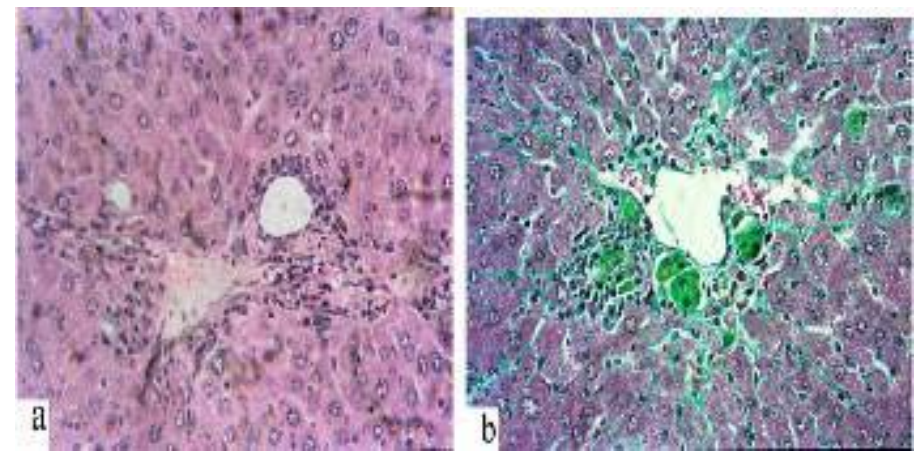

Fig. (4-2) Section from liver tissue of G1 showing mild portal lymphocytic infiltrate, no ballooning degeneration (a: H\&E X400, b: Masson Trichrome X400).
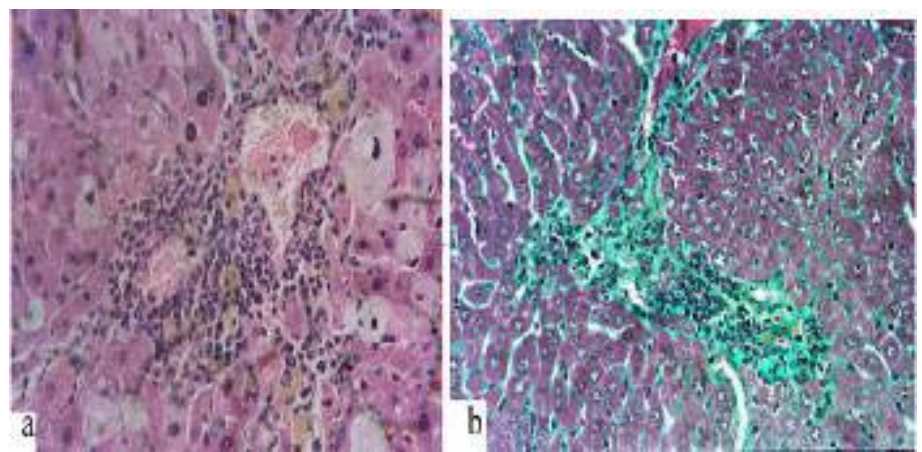

Fig. (4-3) Section from liver tissue of G2 showing moderate portal lymphocytic infiltrate, moderate ballooning degeneration (a: H\&E X400, b: Masson Trichrome X400).
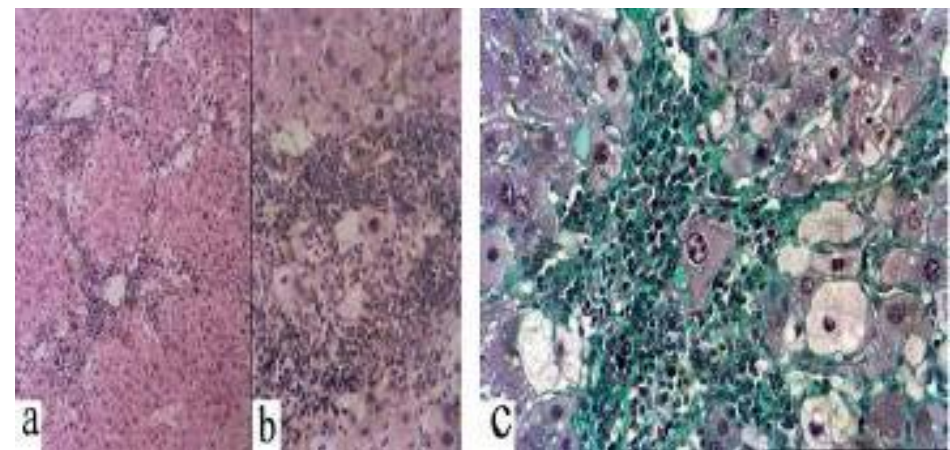

Fig. (4-4) Section from liver tissue of G3 showing severe portal lymphocytic infiltrate, moderate ballooning degeneration and piecemeal necrosis (a: H\&E $X 100$, b: high power magnification $H \& E$ X400 and c: Masson Trichrome X400) Fig. (4) H\&E and Masson Trichrome staining in all 4 groups liver tissue 


\section{REFERENCES}

1. Amarapurkar A, Rege J, Joshi A, Vaiphei K, Amarapurkar D. (2006): Utilization of antihepatocyte clone OCH1E5 (Hep Par 1) in histological evaluation of liver tumors. Indian J Pathol Microbiol.; 49(3):341-4.

2. Di Campli C, Gasbarrini G, Gasbarrini A. (2003): A medicine based on cell transplantation-is there a future for treating liver diseases? Aliment Pharmacol Ther; 18:47380.

3. Di Campli C, Piscaglia AC, Pierelli L, Rutella S, Bonanno G, Alison MR, Mariotti A, Vecchio FM, Nestola $M$, Monego G, Michetti F, Mancuso S, Pola P, Leone G, Gasbarrini G, Gasbarrini A. (2004): A human umbilical cord stem cell rescue therapy in a murine model of toxic liver injury. Dig Liver Dis; 36(9):603-13.

4. Fang B, Shi M, Liao L, Yang S, Liu Y, Zhao RC. (2004): Systemic infusion of FLK1+ Mesenchymal stem cells ameliorates carbon tetrachlorideinduced liver fibrosis in mice. Transplantation; 78: 83-88.

5. Kakinuma S, Tanaka Y, Chinzei $R$, Watanabe $M$, Shimizu- Saito K, Hara Y, Teramoto K, Arii S, Sato C, Takase $\mathrm{K}$, Yasumizu $\mathrm{T}$, Teraoka H. (2003): Human umbilical cord blood as a source of transplantable hepatic progenitor cells, Stem Cells; 21 217-227.

6. Knodell RG, Ishak KG, Black WC, Chen TS, Craig R,
Kaplowitz N, Kiernan TW, Wollman J. (1981): Formulation and application of a numerical scoring system for assessing histological activity in asymptomatic chronic active hepatitis. Hepatology; 1: 431-5.

7. Milteny S., Muller W., Weichel W., Radburch A (1990): High gradient magnetic cells separation with MACS. Cytometry; 11:2318.

8. Sakaida I, Terai S, Yamamoto $\mathbf{N}$, Aoyama $\mathrm{K}$, Ishikawa $\mathbf{T}$, Nishina H, Okita K (2004): Transplantation of bone marrow cells reduces carbon tetrachloride induced liver fibrosis in mice. Hepatology; 40(6):1304-11.

9. Riordan H, Kyle Chan, Annette M, and Thomas E (2007): Cord blood in regenerative medicine: do we need immune suppression? J Transl Med. 2007; 5: 8. Published online 2007 January 30. doi: 10.1186/1479-5876-5-8.

10. Shi MX, Fang BJ, Liao LM, Yang SG, Liu YH, Zhao CH. (2005): Flk1+ mesenchymal stem cells ameliorate carbon tetrachloride-induced liver fibrosis in mice. Sheng Wu Gong Cheng Xue Bao; 21(3):396-401.

11. Shyu MK, Yuan RH, Shih JC, Wu MZ, Chene HL, Kuo Y, Chien L, Chowg LP, Chenh HL, and Hsieh FJ. (2007): Kinetics and functional assay of liver repopulation after human cord blood transplantation Digestive and Liver Disease; 39:455-465

12. Stevens A. (1990): Staining techniques. In: Theory and practice of histological techniques. 3,d ed., John DBancroft (ed) (1990). 
13. Strober W (2001): Trypan blue exclusion test of cell viability. Curr Protoc Immunol.; Appendix 3: Appendix 3B

14. Tanabe $Y$, Tajima $F$, Nakamura Y, Shibasaki E, Wakejima $M$, Shimomura T, Murai R, Murawaki Y, Hashiguchi K, Kanbe T, Saeki T, Ichiba $M$, Yoshida Y, Mitsunari M, Yoshida S, Miake J, Yamamoto Y, Nagata N, Harada T, Kurimasa A, Hisatome I, Terakawa N, Murawaki Y, Shiota G. (2004): Analyses to clarify rich fractions in hepatic progenitor cells from human umbilical cord blood and cell fusion. Biochem Biophys Res Commun; 324:711-8.

15. Terai S, Sakaida I, Yamamoto $\mathrm{N}$, Omori $\mathrm{K}$, Watanabe $\mathrm{T}$, Ohata S, Katada T, Miyamoto K, Shinoda K, Nishina $H$, Okita K. (2003): An in vivo model for monitoring transdifferentiation of bone marrow cells into functional hepatocytes. J Biochem (Tokyo); 134:551-558.

16. Wagner J. (1995): Umbilical cord blood transplantation. Transfusion; 35(8):619-621.

17. Wagner J, Kernan N, Steinbuch $\mathrm{M}$, Broxmeyer $\mathrm{H}$, Gluckman $\mathrm{E}$ (1995): Allogeneic sibling umbilical-cord-blood

transplantation in children with malignant and non-malignant disease. Lancet; 346:214-219.

18. Wang $X, G e S$, McNamara $G$, Hao QL, Crooks GM, Nolta JA (2003): Albumin-expressing hepatocyte-like cells develop in the livers of immune-deficient mice that received transplants of highly purified human hematopoietic stem cells. Blood; 101:4201-4208.

19. Yagi K, Kojima M, Oyagi S, Ikeda $E$, Hirose $M$, Isoda $K$, Kawase M, Kondoh M, Ohgushi H.(2008): Application of mesenchymal stem cells to liver regenerative medicine. Yakugaku Zasshi; 128(1):3-9.

$$
\begin{aligned}
& \text { الزرع المبكر لخلايا الحبل السري الجذعية قد يحسن أستجابة الكبد في الفئران المصابة } \\
& \text { بالتليف الكبدي الناتج من رابع كلوريد الكربهن }
\end{aligned}
$$

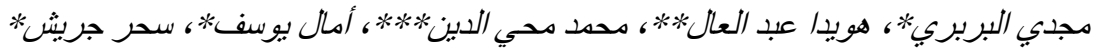

$$
\begin{aligned}
& \text { قسم الفسيولوجي * و الباتولوجي ** و الباطنية*** ـ كلية الطب ـ جامعة قناة السويس } \\
& \text { أظهرت الدر اسات الحديثة أمكانية استخدام الخلايا الجذعية البشرية من دم الحبل السري كمصدر للخدايا }
\end{aligned}
$$

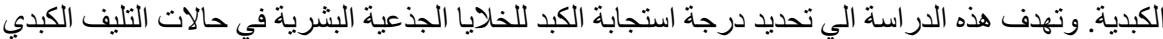

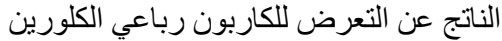

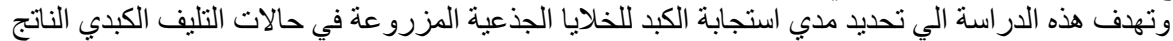

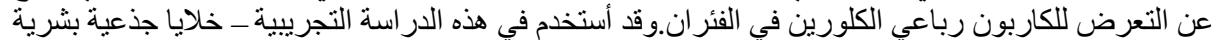

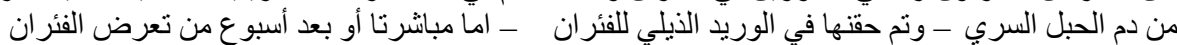

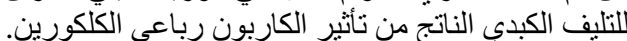

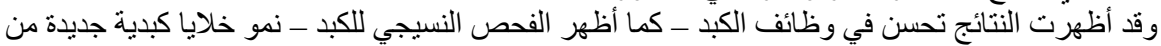

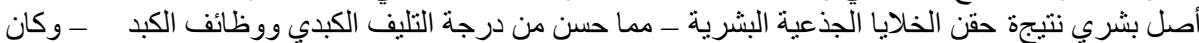

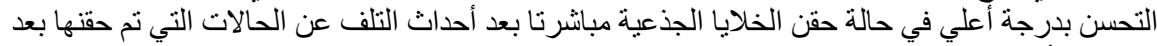

$$
\begin{aligned}
& \text { الإصابة بأسبوع. }
\end{aligned}
$$

